\title{
Legal Culture, Legal Worldview, and Legal Awareness of Subjects in Philosophical and Culturological Discourse
}

\author{
Olga A. Andreeva ${ }^{1}$, Andrei Yu.Mordovtsev ${ }^{2,3}$, Oleg M. Shtompel ${ }^{4}$, Alla A.Timofeeva ${ }^{2}$ \& Magomedrasul M. \\ Shuaipov $^{5}$ \\ ${ }^{1}$ Department of Theory and History of State and Law, Taganrog Institute of Management and Economics, \\ Russia \\ ${ }^{2}$ Department of Theory and History of Russian and Foreign Law, Vladivostok State University of Economics \\ and Service, Russia \\ ${ }^{3}$ Department of Theory and History of State and Law, Rostov Institute (branch) of All-Russian State University \\ of Justice, Russia \\ ${ }^{4}$ Department of Theories of Culture, Ethics, Aesthetics Southern Federal University, Russia \\ ${ }^{5}$ Department of State and Legal Subjects, Rostov Institute (branch) of the All-Russian State University of Justice, \\ Russia \\ Correspondence: Olga A. Andreeva, Department of Theory and History of State and Law, Taganrog Institute of \\ Management and Economics, Russia. E-mail: aum.07@mail.ru
}

Received: June 9, 2019

doi:10.5539/jpl.v12n5p129
Accepted: August 25, $2019 \quad$ Online Published: August 31, 2019

URL: https://doi.org/10.5539/jpl.v12n5p129

\begin{abstract}
This article points out and addresses problematic issues related to the nature of the legal culture, legal worldview, and legal awareness of legal entities. Within the framework of the philosophical-legal and cultural discourse, the authors of the study reveal the existing "semantic layers" regarding the essence of legal culture, its structure and manifestations, as well as the determining influence on the content of the legal world outlook, methods (forms) and results of dissemination of legal information. The article involves theoretical and methodological aspects of studying the national legal culture and legal consciousness, developed by various representatives of the Russian classical legal and philosophical-legal schools (I.A. Iliin, N.S. Trubetskoi, N.N. Alekseev and others).
\end{abstract}

Keywords: legal culture, legal awareness, legal worldview, legal values, law, semiosphere, socialist law

\section{Introduction}

Legal awareness of citizens as a complex and non-linear (in terms of its logical modeling) process of bringing legal information to its addressees, of course, does not occur in a kind of "sociocultural vacuum", but always takes place in a very rich social and regulatory, legal, and political environment.

It should be especially noted that the movement of legal information always takes place in a far from "non-transparent" national space, which is called legal awareness from a pure, ready-to-formal and meaningful perception of justice, but in a very dense and often sustainable nature of powerful sub-normative regulation religious, ordinary, communal, ritual-symbolic, etc. In this regard, a simple build-up of various legal and regulatory structures, laws and, moreover, by-laws do not and cannot lead to any tangible positive changes. A striking example of the last decade is the experience of fighting corruption in different echelons of the Russian government, when the adoption of whole packages of anti-corruption acts promoted by the president of the country in 2008-2009 did not give (according to the recognition of the head of state) any serious results: due to many factors, this legal information simply did not fulfill its program-preventive function. Therefore, any attempts at a "mechanical" study of the process of legal awareness, of the presentation of this process, such as "signal-response-result", are either generally bound to fail or unproductive.

In general, social, civilizational, ethnic-cultural realities are such that the relation between the process of legal awareness of citizens and a multidimensional phenomenon such as the legal culture of society will always be bilateral: the first is one of the most important factors in the evolution of legal culture, changes in its content, while the latter is "semiosphere" (dialectically associated with the state-legal regime, and with other components 
of the national political-legal and cultural space) for the formation and functioning of the legal information system. The recognition of this kind of "reciprocating" relations between these phenomena allows us to build and use quite productive and adequate theoretical and methodological "heuristics".

The subjects of legal life never build their behavior in isolation from their spiritual roots, which emerged during the change of generations of social and legal experience, recognized and already customary legal values, etc. Many representatives of the Russian school of philosophy at the turn of the XIX-XX centuries, and later, in the first half of the XX century (in forced emigration), wrote about the inadmissibility and even the danger of the domination of the formal understanding of the law and the state

\section{Methodological Framework}

Works by I.A. Iliin, N.A. Berdiaev, N.O. Losskii, the founder of the Eurasian movement N.S. Trubetskoi, N.N. Alekseev and others, who, even despite the differences in their positions regarding many state legal and philosophical issues, still believed that the actual functioning of any laws in some way was possible only when they relied on their own moral (in a broad understanding of the latter) postulates. In the domestic classical philosophy of law, all legal and political institutions have always somehow "dissolved" in the space of national culture, subjected to a historical and spiritual dimension

\section{Main Part}

This philosophical and legal tradition does not recognize some "objective goodness" and "objective utility" of any laws, any constitutions and, accordingly, the legal information they contain: the level of consistency of the latter with the ideas of the majority of citizens or subjects about justice, expediency, order, the permissible measure of an individual's legal freedom, the degree of morality of legal regulations, etc., is ensured by what is called the legitimacy of regulatory law acts and is recognized as a condition for their action.

I.A. Iliin expressed this idea in his work "On the essence of legal awareness": "People still have not mastered the basic axiom of any policy, according to which law and the state are created for the inner world and are realized through legal consciousness. Both in science and in life, the formal understanding of the state still prevails, distorting its nature and corrupting in its souls all the basic principles of citizenship. Following this understanding, people build public life as if it came down to the known, mechanically performed, external actions, detached from the inner world and spiritual roots of the human..." [Iliin, 1993].

V.N. Siniukov arguing, in general, within the framework of the same research position, noted that the crisis of spirituality, crime, violence, loss of life-long landmarks, the decline of morality in Western European countries are progressing against the background of perfectly developed formal legal systems, which, with all their logical perfection and rationality, "in terms of their efficiency and humanity, sometimes cannot be compared with" simple" - traditional, ordinary, moral-religious, micro-legal regulators" [Siniukov,1994].

In general, the cognitive situation in the modern theory of law, in the development of the whole legal science at the turn of the XX-XXI century is connected with the need to revise the content of the very concept of law, which does not and simply cannot have "eternal", "absolute" verification, however, anyhow it is always tied to changing scientific paradigms, all sorts of cultural and civilizational processes.

S.S. Alekseev wrote that "law - the regulator" - is a special category, solid and "theoretically saturated", heading a specific conceptual series (it also includes such concepts as the mechanism of legal regulation, legal means, legal regime, etc.). On the basis of this category, as well as all the related concepts, it turns out to be possible, without detaching from legal ground and taking full advantage of the initial data of jurisprudence, in another point - following the coverage of the institutional nature of law - to cross the line of legal dogma, essential in legal knowledge and yet quite narrow in its theoretical potencies. It is possible in such a way that opens a new vision of positive law, its logic, with a new group of questions of the general theory, no less essential than the characterization of law as an objective reality, its features as an institutional entity. The essence of the "new angle of view" on law lies in the fact that the concept of legal regulation is the starting point and unifying beginning of the characteristics of law in action, in motion, in the process of implementing its potential and power" [Alekseev, 2007].

In this sense, there are at least three problems:

1) the institutional structure of the mechanism (or system) of legal regulation;

2) factors determining the specificity and results of the "law in action";

3) criteria for the operating efficiency (or optimality) of the mechanism of legal regulation, moreover, not "in general" (this question has already been theoretically elaborated in the special literature), but in a specific 
(national) legal space, in a certain, this ("here and now "- G.V.F. Hegel) historical epoch, and therefore under some type of legal system and state (for example, a transitional state and law, a stable, stable state of political and legal life, etc.).

It is also clear that the new theoretical and methodological "angle" of legal thinking, namely the transition from the study of legal dogma, the static condition of positive law as a kind of "regulatory and protective" product of the will of the sovereign (state) and by virtue of this already endowed and objective character, and the "absolute" social value of the institution to legal dynamics implies a focus on the study of key issues of the legal culture of society, and therefore on such its elements as legal information, legal awareness (legal information dimension of life), legal philosophy, and legal consciousness (spiritual or "ideal" aspects of legal culture).

We should point out that during the Soviet period of development of legal science, some results were achieved in the above-mentioned field of knowledge, but due to the characteristics and principles of the dominant Marxist-Leninist methodology, the research framework, for example, such a phenomenon as legal culture was very narrow, which often led to the substitution of concepts: "legal culture" moved aside to the periphery of legal and philosophical knowledge, and the more consonant with Marxist terminology category of "legal superstructure", etc., came to the foreground.

A certain theoretical and methodological breakthrough, however, was in the 60-80s, when the theoretical and legal literature outlined several approaches to understanding the phenomenon of "legal culture", or rather, the structural elements (components) of the latter. We should note here that interest in legal culture in this period is far from accidental: a brief political "thaw" and the subsequent era of "socialist stability" stimulated the need for a new ("Non-Stalin") understanding of the nature of "socialist state", "socialist legality", "communist state-legal construction", etc., in this regard, the appeal to the legal culture of socialist society allowed to provide some meaningful and substantive unity, general methodological benchmarks and principles in the study of various fragments of the Soviet state-legal reality.

In addition, we should clarify that the Soviet "heuristic patterns" of legal culture were not of some kind of "legal and metaphysical" character but fully practical, oriented, pragmatically and functionally defined, which, naturally, is important for the modern information dimension of law, legal system, legal life, legal policy, etc.

S.S. Alekseev wrote: "Legal culture is a combination of knowledge, skills of applying, following, and using laws, as well as their deep respect" [Alekseev, 1966]. In later work, the same author noted a slightly different facet of legal culture: "This is a state of sense of justice, legality, the perfection of legislation and legal practice, expressing the approval and development of law as a social value" [Alekseev,1972].

As part of the study of the socialist discourse of legal culture, based on the cognitive tasks and methodological guidelines of this study, it is important to focus on the search for the relationship of legal culture and legal education as the most important and integral component of ideological work, which, as is well known, was the first priority in the USSR. In this context V.I. Kaminskaia and A.R. Ratinov suggest understanding legal culture as "a system of objectified (materialized) and ideal elements belonging to the sphere of action of law, and their reflection in the consciousness and behavior of people" [Kaminskaia,1974].

Let us remark here that understanding legal culture will be the priority for 2-3 decades for the domestic theory of law and the state, which, of course, does not mean the absence of other definitions (their number will only increase) but presupposes following the logic of understanding this phenomenon: in the legal culture one always seeks to find and fix two groups of elements - "actual" or "objective", on the one hand, and hidden or spiritual (ideal), on the other.

E.V. Kuznetsov, V.P. Salnikov, and I.V. Avseev think in the same vein, asserting the possibility of understanding the legal culture in a broad (set of elements of the legal superstructure in their real functioning) and narrow (development of social qualities of a person, characterizing their sense of justice, the specifics of social experience, etc.) sense [Avseev, et al 1979].

Deep down, such a theoretical and methodological perspective on the study of legal culture, with all its seemingly heuristic "reconciliation", has at least two drawbacks:

1) the authors strive to incorporate into the legal culture, in fact, all elements of the national legal reality, therefore it is now quite difficult to separate such categories as "legal system", "legal life", and "legal superstructure" at the conceptual level;

2) already at the actual (and later at the functional) level of legal culture, the question arises about the mechanism of interconnection and interaction of the objectified components of legal culture (the legal system, i.e. the structure of law by branches and institutions, legal relations, legal institutions and etc.) and its "subjective 
structures": legal consciousness, legal behavior, legal experience, legal ideology, etc. The authors, as a rule, use the concepts of "reflection" or "spiritual reflection" of legal reality, which, however, do not give an opportunity to see the diversity of "subject-object" relations in the space of the national legal culture (the concept of "reflection", in particular, simply fixes the formation at the level of public or personal legal consciousness of certain "legal images", perhaps, assessments in relation to different elements of the legal space surrounding the subject, but does not include personal characteristics of the individual and society in the legal sphere). In this situation, we are "dealing" not with a single entity - legal culture, but with entities of a different order (regulatory, institutional, spiritual, etc.).

The theoretical and methodological pluralism, typical of post-Soviet domestic legal science, naturally generated a huge (approximately 200 definitions different or similar in content and meaning) number of conceptualizations of legal culture: from globalist-progressive and incredibly broad in scope and scope to specific enough and even in our opinion, excessively "narrow".

In this respect, in the framework of the subject of our research, the point of view of A.S. Bondarev, who "moves" the process of understanding the nature of legal culture to a subjectivistic methodological plane, comes under notice: "The separation of legal culture from legal subjects, its creators and carriers makes it unapproachable" [Bondarev, 2012].

The researcher provides completely clear arguments, primarily because of their obvious practical accentuation. A.S. Bondarev believes (and in the context of the informational dimension of legal culture and law it is difficult to argue with this) that any definition of legal culture is appropriate only when it allows the search for ways to influence this phenomenon. "How, for example, can we purposefully influence the aggregate of legal values developed by mankind or "the system of materialized and ideal elements falling within the scope of the law", etc. objects, since they are insensitive" [Bondarev, 2012].

Therefore, the lawyer offers his own version of the definition of legal culture, allowing, as he thinks, to carry out various kinds of changes in its content: modernize, "liberalize", etc.

"The category of "legal culture" should characterize not some legal values, but subjects of law, both collective and individual. Legal culture is the legal property of subjects of law. It is the degree of their legal development, legal excellence, the level of their ability to qualitatively create and effectively use the necessary legal means to achieve their legitimate goals, their legitimate interests, and needs and embody these abilities in the socio-legal activity" [Bondarev, 2012].

In addition, it is worth noting another aspect, which is certainly important in terms of understanding such a subjective approach to the consideration of legal culture, namely that, as a matter of law itself, legal culture arises only in the society where other social regulators, and accordingly, the cultural forms they generate due to the action of various factors, lose their regulatory and protective resource and, thereby, cause the appearance of such a special phenomenon (first of all, according to the method of its provision) as the right expressed in different sources and giving rise to the emergence of legal relations and, naturally, of the semiosphere (basics of legal existence and development), which we call the legal culture.

While within the current state of theoretical and legal science, it is obvious that legal means necessary for the sustenance of a controversial (rather than "archaic-harmonious", like the peasant community of the pre-revolutionary period) and socially heterogeneous society, in turn, suggest the emergence of a special kind of subjects - carriers of legal consciousness, or rather (to get away from yet another extremely difficult for an unambiguous both philosophical and legal interpretation of the term "consciousness") - the legal worldview. The latter serves as the spiritual and intellectual basis for the perception and evaluation of legal information.

Therefore, following specific cognitive goals, it makes sense to reduce the legal culture of the subject (as, for example, A.S Bondarev understands it) to its legal worldview, which will allow avoiding all sorts of extraneous "connotations" that impede the study of legal information and legal awareness.

Actually, this logical-semantic reduction, among other things, will make it possible to critically evaluate such judgments as "... legal culture is possible only when legal entities will "like" the law after they "bypass" their legal field many times. i.e. when they are convinced that the existing law truly expresses both their and public interests" (optimally approves the balance of personal and public interests) [Bondarev, 2012].

\section{Summary}

A broad logical-semantic and structural reconstruction of the above definitions of the concept of "legal culture", including its subjective ("narrow") version, which allows reducing this kind of understanding of the nature of legal culture from an informational and legal standpoint, where an accumulation and a special kind of 
intellectual-value "processing" of legal information takes place, i.e. the multilevel process of mastering legal knowledge, legal requirements of society, and problems in law enforcement and legislative practice, the work of law enforcement agencies, etc., it is necessary to identify a number of important points:

1) legal subjects (individuals and legal entities) actually live and function not in the legal, but in the information and legal field. Law as a social institution, an important regulatory and protective form of culture has many types of its understanding, some of which, in general, are "polar" in their content: for example, statist-positivistic interpretations of law differ fundamentally from the natural-law version of legal thinking, and the latter can hardly be understood in historical-conservative or psychological legal discourses. However, legal space exists; both in logical and functional terms, it is always "identical to itself", and for subjects of legal relations, at least in practical terms, it does not appear "in a variety of definitions", which are just a doctrinal type of legal information, but always act as a normative or other information necessary for stable, effective legal communication, an adequate understanding of which by different subjects ensures, ultimately, action of information and legal "constructs" (signals), as the legal permission, positive binding, and legal prohibitions. In such a context, not legal consciousness "serves as a measure of the state of the legal system as a whole, contributing to its necessary changes", but the quality of legal information anyhow coming to the subjects, its conformity to social ideas about justice ("Truth" in the traditional Russian legal discourse), legal interest, law and order, etc. and the level of legal awareness of the society, its various circles, classes, and strata, their ability to perceive the general legal principles, the content of at least the most important, fundamental legal acts (the Constitution, civil and criminal code, etc.) determine the different-vector (modernizing or, otherwise, conservative, reformist, adaptive, or revolutionary) "movements" of the national system of legislation and law. Modern political life is also not free from the information and legal impact experience by its subjects. In this regard, we categorically disagree with the opinion of J. Carbonier, who believes that "a person with a developed legal conscience does not really need information about the law..., with such legal awareness, a citizen will be able to understand what is legal" [Vengerov, 1997; Jenaabadi, \& Khosropour,2014]. This is most likely a manifestation of some kind of "legal anarchism" or "legal avant-garde", typical of, for example, the period of the domination of "revolutionary legal consciousness" in Russia in 1917-1924;

2) within the framework of the national legal culture, based on the specifics of the legal worldview that has been formed in a specific historical period, there is always an information and legal strategy formed by the power elites due to different (social, political, ideological, etc.) factors and the presence of certain interests, which is a method, a general plan for achieving the goals in doctrinal law, lawmaking, law enforcement, and law interpretation. The information and legal strategy relates to practical activity and, is somehow implemented by all the subjects involved therein through special strategic behavior. The main goal of the legal information strategy, both now and previously, is the effective use of existing regulatory, conceptual, and institutional resources for the preservation and development of the national or (as in the context of globalization) supranational legal space, including "landmark" (legal and regulatory), legal-theoretical, and practical-activity components (institutions, structures).

\section{References}

Alekseev, S. S. (1966). The mechanism of legal regulation in a socialist state. M.

Alekseev, S. S. (1972). Problems of the theory of law. Sverdlovsk.

Alekseev, S. S. (2007). Law. Alphabet. Theory. Philosophy. Experience of a comprehensive study. M.

Avseev, I. V., Kuznetsov, E. V., \& Salnikov, V. P. (1979). The theory of state and law (definitions, schemes, literature). M.

Baranov, P. P., \& Okusov, A. P. (2003). Axiology of legal activity. Rostov-on-Don.

Bondarev, A. S. (2012). Legal culture as a factor in the life of the law. M.

Iliin, I. A. (1993). On the essence of justice. Munich.

Jenaabadi, H., \& Khosropour, A. (2014). An Investigation on the Amount of Employing Total Quality Management Principles by School Principals and Its'Correspondence with Their Affectivity. UCT Journal of Social Sciences and Humanities Research, 2(1), 13-17.

Kaminskaia, V. I., \& Ratinov A. R. (1974). Legal culture and issues of legal education. M.

Mordovtsev, A. Iu., \& Popov, V. V. (2007). Russian legal mentality. Rostov-on-Don.

Poliakov, A. V. (2001). The general theory of law. St. P. 
Siniukov, V. N. (1994). Russian legal system: Introduction to the general theory. Saratov.

Vengerov, A. B. (1997). Theory of state and law (Part 2, Vol 2). M.

Voplenko, N. N. (2000). Legal awareness and legal culture. Volgograd.

\section{Copyrights}

Copyright for this article is retained by the author(s), with first publication rights granted to the journal.

This is an open-access article distributed under the terms and conditions of the Creative Commons Attribution license (http://creativecommons.org/licenses/by/4.0/). 